\title{
The impact of smoking cessation on patient quality of life $\mathrm{e}^{*, * *}$
}

\author{
Impacto da cessação tabágica na qualidade de vida dos pacientes
}

\author{
Maria Penha Uchoa Sales, Maria Irenilza Oliveira, lsabela Melo Mattos, \\ Cyntia Maria Sampaio Viana, Eanes Delgado Barros Pereira
}

\begin{abstract}
Objective: To evaluate changes in health-related quality of life (HRQoL) after twelve months of smoking cessation. Methods: This was a prospective study to evaluate the effectiveness of a smoking cessation program on the quality of life of 60 self-referred subjects, at a public hospital, during the period of August 2006 to December 2007. The program consisted of 2-h group sessions once a week during the first month and then every 15 days over six months, followed by monthly phone contacts for another six months. The treatment was based on behavior modification and the use of bupropion in combination with nicotinic replacement therapy. Abstinence was verified by exhaled CO measurements. Patient HRQoL was quantified using the Medical Outcomes Study 36-item ShortForm Health Survey (SF-36) questionnaire. Differences in quality of life scores between quitters and non-quitters at twelve months after the initial intervention were evaluated using analysis of covariance with baseline characteristics as covariates. Results: Self-reported quality of life scores were significantly higher among the 40 quitters than among the 20 non-quitters. The following SF-36 domains were most affected: role-emotional $(p=0.008)$; general health $(p=0.006)$; vitality $(p<0.001)$; and mental health $(p=0.002)$. At twelve months after the smoking cessation intervention, the SF-36 mental component and physical component summary scores were higher among quitters than among non-quitters ( $p=0.004$ and $p=0.001$, respectively). Conclusions: Our findings illustrate that smoking abstinence is related to better HRQoL, especially in aspects of mental health.
\end{abstract}

Keywords: Quality of life; Smoking cessation; Questionnaires.

\section{Resumo}

Objetivo: Avaliar alterações na qualidade de vida relacionada à saúde (QVRS) doze meses após a cessação tabágica. Métodos: Estudo prospectivo para avaliar a efetividade de um programa de tratamento de fumantes, em relação à qualidade de vida, com 60 pacientes atendidos em um hospital público no período de agosto de 2006 a dezembro de 2007. 0 programa consistiu de sessões em grupo semanais com $2 \mathrm{~h}$ de duração durante o primeiro mês e quinzenais até o sexto mês, seguidas por telefonema mensal durante mais seis meses. 0 tratamento foi baseado na mudança comportamental e no uso de bupropiona associada à terapia de reposição nicotínica. A abstinência foi aferida pela medida de CO exalado. A QVRS dos pacientes foi quantificada através do questionário Medical Outcomes Study 36-item Short-Form Health Survey (SF-36). Diferenças nos escores de qualidade de vida entre ex-fumantes e fumantes ativos doze meses após a intervenção inicial foram analisadas utilizando-se a análise de covariância com as características basais como covariáveis. Resultados: Os escores de qualidade de vida autorrelatados foram significativamente maiores nos 40 ex-fumantes do que nos 20 fumantes ativos. Os seguintes domínios do SF-36 foram mais afetados: papel emocional $(p=0,008)$; saúde geral $(p=0,006)$; vitalidade $(p<0,001)$ e saúde mental $(p=0,002)$. Doze meses após a intervenção para a cessação tabágica, os escores dos componentes físico e mental sumarizados foram maiores nos ex-fumantes do que nos fumantes $(p=0,004$ e $p=0,001$, respectivamente). Conclusões: Nossos achados ilustram que a abstinência tabágica está relacionada à melhora da QVRS, especialmente nos aspectos relacionados à saúde mental.

Descritores: Qualidade de vida; Abandono do hábito de fumar; Questionários.

\footnotetext{
* Study carried out at the Dr. Carlos Alberto Studart Gomes Hospital de Messejana, Fortaleza, Brazil.

Correspondence to: Maria da Penha Uchoa Sales. Rua Gothardo Moares, 155/1002A, Papicu, CEP 60190-801, Fortaleza, CE, Brasil.

Tel 5585 3486-6004. E-mail: penhauchoa@hotmail.com

Financial support: None.

Submitted: 5 September 2008. Accepted, after review: 10 November 2008.

**A A versão completa em português deste artigo está disponível em www.jornaldepneumologia.com.br
} 


\section{Introduction}

Current smokers account for one in three adults worldwide ( 1.1 billion people), and $80 \%$ of these live in middle- or low-income countries. ${ }^{(1)}$ Smoking is responsible for the death of one in ten of these individuals, corresponding to approximately 5 million unnecessary deaths each year. ${ }^{(2)}$ A prospective study of 34,000 male British doctors showed that, although prolonged cigarette smoking triples mortality rates, cessation at age 30 averts nearly all of this increased risk. ${ }^{(3)}$ The total number of smokers is expected to reach about 1.6 billion by 2025 , with the annual number of tobacco-related deaths expected to reach 10 million by 2030; 70\% of these deaths will occur in developing countries. ${ }^{(1)}$

Knowledge of the impact of smoking cessation on health-related quality of life (HRQoL) can be important in encouraging smokers to quit. A successful smoking-cessation attempt involves addressing the physical, psychological and emotional addiction to nicotine. Several studies have examined HRQoL among current smokers, former smokers and nonsmokers, ${ }^{(4-7)}$ showing that HRQoL is better among nonsmokers and former smokers than among current smokers. However, most such studies have defined smoking abstinence based on patient self-reports. To date, there is scarce information regarding potential changes in HRQoL that can be provided to smokers who are trying to quit. Nor have there been many studies in which the determination of exhaled CO was used as a means of verifying abstinence.

The aim of the present study was to compare the overall perceived health status of patients in whom smoking abstinence is confirmed biochemically with that of those who continue to smoke after participating in a smoking cessation program for one year.

\section{Methods}

\section{Study design and measurements}

We evaluated 60 patients enrolled in the smoking cessation program of a tertiary-referral cardiothoracic hospital in the city of Fortaleza, Brazil. The study period was from August of 2006 to August of 2007.
This was a prospective study involving patients 18 years of age or older. Over a onemonth period, the patients were motivated to quit smoking using the stages of change model devised by Prochaska \& DiClemente. ${ }^{(8)}$ Exclusion criteria were inability to attend group sessions and loss to follow-up. The study design was approved by the institutional review board of the hospital. All participating patients gave written informed consent.

The program consisted of face-to-face first interview counseling to identify risk factors for smoking maintenance and to individualize advice regarding quitting. This was followed by group counseling sessions. In the first medical evaluation, the patients were interviewed in order to collect sociodemographic data, as well as information regarding current smoking, prior smoking, previous quit attempts (number and methods used), medical history (comorbidities), current drug therapy, Fagerström test for nicotine dependence (FTND) score and motivation for quitting.

The group sessions were based on behavior modification counseling and were all conducted by the same team, composed of a social worker and a physician. The group counseling consisted of 2-h sessions, held once a week during the

Table 1 - Baseline characteristics of the patients evaluated $(n=60)$. ${ }^{\text {a }}$

\begin{tabular}{lc}
\hline \multicolumn{1}{c}{ Characteristic } & Value \\
\hline $\begin{array}{l}\text { Age in years, mean } \pm \text { SD } \\
\text { Gender }\end{array}$ & $54 \pm 10$ \\
$\quad$ Female & $29(48.4)$ \\
$\quad$ Male & $31(51.6)$ \\
Level of education & \\
$\quad$ llliterate & $4(6.8)$ \\
$\quad$ Elementary school & $21(35.0)$ \\
$\quad$ High school & $23(38.2)$ \\
$\quad$ College & $12(20.0)$ \\
Marital status & \\
$\quad$ Married & $32(53.4)$ \\
$\quad$ Other (widowed, separated, & $28(46.6)$ \\
divorced or single) & \\
Nicotine dependence & \\
$\quad$ Mild & $12(20.0)$ \\
Moderate/severe & $48(80.0)$ \\
Cigarettes smoked/day, mean \pm SD & $39.2 \pm 19.6$ \\
\hline
\end{tabular}

avalues expressed as $n(\%)$, except where otherwise indi-

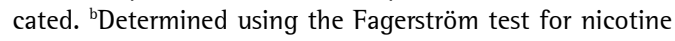
dependence. 
first month and then every two weeks over a six-month period, after which phone contact was made monthly for another six months. The methods were standardized and were used in each of the smoking cessation groups. The combination of nicotine replacement therapy and bupropion was recommended based on physician prescription. The nicotine replacement therapy and the medication were provided free of charge.

Abstinence was chemically verified by determining exhaled CO. Patients were considered abstinent if they registered less than $10 \mathrm{ppm}$ on the test and if they self-reported cessation.

The HRQol was quantified based on the scores obtained using the Medical Outcomes Study 36-item Short-Form Health Survey (SF-36), which was administered at baseline and at the end of the program (after twelve months).

The SF-36 includes eight domains (physical function, role-physical, bodily pain, general health, vitality, social functioning, role-emotional and mental health), as well as two summary components (physical and mental). Each domain/component score ranges from 0 to 100 points, higher scores indicating better HRQoL. ${ }^{(9,10)}$
The FTND scores range from 0 to 10 , addiction being classified as mild (score, 0-4), moderate (score, 5) or severe (score, 6-10) ${ }^{(11)}$

\section{Statistical analysis}

Statistical analysis was undertaken using the statistical software Statistical Package for the Social Sciences, version 11.0 (SPSS Inc., Chicago, IL, USA). Descriptive statistics were summarized for demographic and social factors. Baseline differences between quitters and non-quitters were analyzed by either Fisher's exact test or independent sample t-tests. Differences between smoking outcome groups at 12 months after the initial consultation were assessed for the SF-36 domains using analysis of covariance with age, gender and Fagerström score as covariates. Values of $p<0.05$ were considered significant.

\section{Results}

The baseline characteristics of the 60 patients are shown in Table 1 . More than half of the patients were men, were married and presented an FTND score indicative of moderate/severe dependence. The mean exhaled CO level was $3 \mathrm{ppm}$ for the quitters and $19 \mathrm{ppm}$ for the non-quitters.

Table 2 - Comparisons between smokers who remained abstinent (quitters) and those who did not (non-quitters). ${ }^{\mathrm{a}}$

\begin{tabular}{|c|c|c|c|}
\hline \multirow[t]{2}{*}{ Factor } & Quitters & Non-quitters & \multirow[t]{2}{*}{$p$} \\
\hline & $(n=40)$ & $(n=20)$ & \\
\hline \multicolumn{4}{|l|}{ Gender } \\
\hline Male & $23(57.5)$ & $8(40.0)$ & 0.27 \\
\hline Female & $17(42.5)$ & $12(60.0)$ & \\
\hline Mean age, years & 53.9 & 52.9 & 0.61 \\
\hline \multicolumn{4}{|l|}{ Marital Status } \\
\hline Married & $23(57.5)$ & $9(45.0)$ & 0.41 \\
\hline Other & $17(42.5)$ & $11(55.0)$ & \\
\hline \multicolumn{4}{|l|}{ Level of education } \\
\hline Illiterate/Elementary school & $17(42.5)$ & $8(40.0)$ & $0.41^{*}$ \\
\hline High school & $13(32.5)$ & $10(50.0)$ & $0.88^{*}$ \\
\hline College & $10(25.0)$ & $2(10.0)$ & \\
\hline \multicolumn{4}{|l|}{ Comorbidtiy } \\
\hline Yes & $24(60.0)$ & $10(50.0)$ & 0.58 \\
\hline No & $16(40.0)$ & $10(50.0)$ & \\
\hline FTND score, mean & 5.6 & 6.6 & 0.02 \\
\hline Smoking history in pack-years, mean & 39.6 & 38.2 & 0.71 \\
\hline Exhaled CO in ppm, mean \pm SD & $2.8 \pm 1.0$ & $19.0 \pm 10.0$ & 0.01 \\
\hline
\end{tabular}

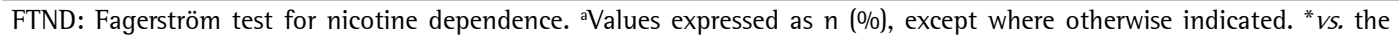
College category. 
Table 3 - Health-related quality of life before and after smoking cessation intervention (covariates: age, gender and Fagerström test for nicotine dependence score). ${ }^{a}$

\begin{tabular}{lccc}
\hline \multicolumn{1}{c}{ SF-36 measure } & Pre-intervention & Post intervention & $p$ \\
\hline Domain & & & 0.052 \\
Physical functioning & $65.75 \pm 4.80$ & $78.00 \pm 1.60$ & 0.034 \\
Role-physical & $68.50 \pm 4.80$ & $88.50 \pm 5.70$ & 0.000 \\
Bodily pain & $58.63 \pm 4.20$ & $81.53 \pm 4.20$ & 0.006 \\
General health & $57.56 \pm 4.70$ & $76.05 \pm 4.50$ & 0.000 \\
Vitality & $59.25 \pm 4.30$ & $84.88 \pm 3.50$ & 0.000 \\
Social functioning & $76.58 \pm 4.60$ & $96.94 \pm 1.50$ & 0.054 \\
Role-emotional & $66.66 \pm 7.10$ & $85.25 \pm 6.50$ & 0.002 \\
Mental health & $62.20 \pm 3.40$ & $80.00 \pm 3.40$ & 0.004 \\
Physical component summary & $43.41 \pm 1.80$ & $50.61 \pm 1.60$ & 0.001 \\
Mental component summary & $46.82 \pm 2.20$ & $56.61 \pm 1.50$ & \\
\hline
\end{tabular}

SF-36: Medical Outcomes Study 36-item Short-Form Health Survey. ${ }^{a}$ Values expressed as $n$ (\%).

Comparisons between the quitters and nonquitters indicated that those presenting a lower FTND score were more likely to quit $(\mathrm{p}=0.02)$. The mean exhaled CO level was lower in the quitter group. There were no other differences between quitters and non-quitters in terms of clinical features, demographics or smoking-related variables (Table 2).

Analysis of covariance of HRQoL from baseline to the end of the program, taking age, gender and FTND score as covariates, revealed that the quitters presented statistically significant improvement in the role-physical, bodily pain, general health, vitality, social functioning and mental health domains, as well as in the physical component summary and the mental component summary ( $p<0.05$ for all; Table 3$)$.
After adjusting for age, gender and FTND score, we found that the quitters presented higher post-intervention scores than did the non-quitters for the general health, vitality, roleemotional and mental health domains, as well as for the mental component summary $(p=0.001$ for all; Table 4).

\section{Discussion}

The major finding of this study is that this particular type of smoking cessation program improves the HRQoL of the enrollees. This is consistent with the findings of other authors, ${ }^{(7,12,13)}$ who found that smokers report poorer health status in general than never and former smokers. In one study, ${ }^{(14)}$ it was demon-

Table 4 - Comparison of between smokers who remained abstinent (quitters) and those who did not (non-quitters) in terms of post-intervention health-related quality of life (covariates: age, gender and Fagerström test for nicotine dependence score). ${ }^{\mathrm{a}}$

\begin{tabular}{|c|c|c|c|}
\hline SF-36 measure & Quitters & Non-quitters & $\mathrm{p}$ \\
\hline \multicolumn{4}{|l|}{ Domain } \\
\hline Physical functioning & $78.9 \pm 4.3$ & $64.3 \pm 6.1$ & 0.05 \\
\hline Role-physical & $88.6 \pm 5.7$ & $81.7 \pm 8.2$ & 0.5 \\
\hline Bodily pain & $82.1 \pm 4.2$ & $72.6 \pm 6$ & 0.2 \\
\hline General health & $77.4 \pm 4.5$ & $52.4 \pm 6.4$ & 0.003 \\
\hline Vitality & $85.3 \pm 3.5$ & $72 . .4 \pm 5.1$ & 0.04 \\
\hline Social functioning & $97.1 \pm 1.7$ & $91.2 \pm 2.5$ & 0.08 \\
\hline Role-emotional & $87.5 \pm 6.3$ & $56.6 \pm 9.1$ & 0.008 \\
\hline Mental health & $81.6 \pm 3.4$ & $58.4 \pm 4.9$ & $<0.0001$ \\
\hline Physical component summary & $50.6 \pm 1.6$ & $46.4 \pm 2.3$ & 0.134 \\
\hline Mental component summary & $56.6 \pm 1.5$ & $47.4 \pm 2.2$ & 0.001 \\
\hline
\end{tabular}

aValues expressed as $n(\%)$. 
strated that cigarette smokers who receive a clinical smoking cessation intervention and who are continuously abstinent from smoking for the subsequent year self-report more improvement in the SF-36 mental component summary at the end of that year than do those who continue to smoke. Similar results have been reported for COPD patients who stop smoking. One cross-sectional survey sought to understand the characteristics of COPD patients who have quit and those who have not quit in order to identify important factors to evaluate in smoking-cessation interventions. ${ }^{(15)}$ In that study, the quitters were older, had more cardiac comorbidities, presented better mental health and better perceived provider-patient interactions in comparison with the non-quitters.

In the present study, the post-intervention mental component summary score was better for the quitters than for the non-quitters. Of the eight SF-36 domains, those most affected were role-emotional, general health, vitality and mental health.

One limitation shared by many of the studies cited is that the definition of smoking abstinence relied on self-reports, and only patients who responded to the follow-up survey were included..$^{(5,14,16-18)}$ In our study, only subjects who self-reported cessation and presented low exhaled CO levels (confirmed abstinence) were classified as quitters.

Behavioral support with appropriate pharmacotherapy was offered to the patients in our program, and all sessions were conducted by the same multidisciplinary team, both of which might have been important factors in bringing about the improvement in quality of life seen among our patients. A study published by the United States Public Health Service showed that physician advice to stop smoking increases abstinence. (19) Another distinct aspect of our study was the fact that we offered free bupropion and nicotine replacement therapy in combinations that were based on patient needs and preferences. There is evidence that the use of a combination of treatments results in greater suppression of tobacco withdrawal symptoms than does that of a single treatment. The nicotine patch-bupropion combination has been approved by the U.S. Food and Drug Administration for smoking cessation. ${ }^{(20)}$

Future studies should determine the clinical usefulness of stratifying smokers to the appropriate pharmacotherapy and the level of intensity of behavioral counseling needed in order to achieve long-term smoking cessation and improve patient HRQoL.

One of the limitations of this current study is that, since there were insufficient resources to measure biochemical abstinence at every visit, we used point prevalence abstinence rates rather than continuous abstinence rates. However, point prevalence is the most practical, costeffective way of assessing outcomes in such studies. In addition, it would have been ideal to include a third group of patients comprising never smokers. Additional studies involving larger samples and control groups are needed in order to determine the relationship between smoking cessation and HRQoL.

Only 60 subjects agreed to participate in the final evaluation. This selection of subjects might limit the generalizability of our results to other clinical settings.

Our findings show that HRQoL, especially dimensions related to mental health, as assessed by the SF-36, can improve after twelve months of smoking abstinence. The results of our analysis can be employed in the education of the smoking patient, thereby contributing to smoking cessation efforts.

\section{References}

1. Bala M, Strzeszynski L, Cahill K. Mass media interventions for smoking cessation in adults. Cochrane Database Syst Rev. 2008;(1):CD004704.

2. World Health Organization. Why is tobacco a public health priority? Geneva: World Health Organization; 2004.

3. Doll R, Peto R, Boreham J, Sutherland 1. Mortality in relation to smoking: 50 years' observations on male British doctors. BMJ. 2004;328(7455):1519.

4. Tillmann M, Silcock J. A comparison of smokers' and ex-smokers' health-related quality of life. J Public Health Med. 1997;19(3):268-73.

5. Wilson D, Parsons J, Wakefield M. The healthrelated quality-of-life of never smokers, ex-smokers, and light, moderate, and heavy smokers. Prev Med. 1999;29(3):139-44.

6. Stewart AL, King AC, Killen JD, Ritter PL. Does smoking cessation improve health-related quality-of-life? Ann Behav Med. 1995;17(4):331-8.

7. Lyons RA, Lo SV, Littlepage BN. Perception of health amongst ever-smokers and never smokers: a comparison using the SF-36 Health Survey Questionnaire. Tob Control. 1994;(3):213-5.

8. DiClemente CC, Prochaska J0. Self-change and therapy change of smoking behavior: a comparison of processes of change in cessation and maintenance. Addict Behav. 1982;7(2):133-42. 
9. Ware JE; New England Medical Center Hospital. Health Institute. SF-36 physical and mental health summary scales: A user's manual. Boston: The Health Institute, New England Medical Center; 1994.

10. Ware JE Jr, Kosinski M, Bayliss MS, McHorney CA, Rogers WH, Raczek A. Comparison of methods for the scoring and statistical analysis of SF-36 health profile and summary measures: summary of results from the Medical Outcomes Study. Med Care. 1995;33(4 Suppl):AS264-79.

11. Heatherton TF, Kozlowski LT, Frecker RC, Fagerström KO. The Fagerström Test for Nicotine Dependence: a revision of the Fagerström Tolerance Questionnaire. $\mathrm{Br} \mathrm{J}$ Addict. 1991;86(9):1119-27.

12. Zillich AJ, Ryan M, Adams A, Yeager B, Farris K. Effectiveness of a pharmacist-based smokingcessation program and its impact on quality of life. Pharmacotherapy. 2002;22(6):759-65.

13. Mulder 1, Tijhuis M, Smit HA, Kromhout D. Smoking cessation and quality of life: the effect of amount of smoking and time since quitting. Prev Med. 2001;33(6):653-60.

14. Croghan IT, Schroeder DR, Hays JT, Eberman KM, Patten CA, Berg EJ, et al. Nicotine dependence treatment: perceived health status improvement with 1-year continuous smoking abstinence. Eur J Public Health. 2005;15(3):251-5.

15. Adams SG, Pugh JA, Kazis LE, lee S, Anzueto A. Characteristics associated with sustained abstinence from smoking among patients with COPD. Am J Med. 2006;119(5):441-7.

16. Olufade AO, Shaw JW, Foster SA, Leischow SJ, Hays RD, Coons SJ. Development of the Smoking Cessation Quality of Life questionnaire. Clin Ther. 1999;21(12):2113-30.

17. Erickson SR, Thomas LA, Blitz SG, Pontius LR. Smoking cessation: a pilot study of the effects on healthrelated quality of life and perceived work performance one week into the attempt. Ann Pharmacother. 2004;38(11):1805-10.

18. Shaw JW, Coons SJ, Foster SA, Leischow SJ, Hays RD. Responsiveness of the Smoking Cessation Quality of Life (SCQoL) questionnaire. Clin Ther. 2001;23(6):957-69.

19. Fiore MC. US public health service clinical practice guideline: treating tobacco use and dependence. Respir Care. 2000;45(10):1200-62.

20. United States. Public Health Service. Treating tobacco use and dependence: 2008 update. Clinical practice guideline. Rockville: U.S. Dept. of Health and Human Services, Public Health Service; 2008.

\section{About the authors}

\section{Maria Penha Uchoa Sales}

Coordinator of the Smoking Control Program at the Dr Carlos Alberto Studart Gomes Hospital de Messejana, Fortaleza, Brazil.

Maria Irenilza Oliveira

Social Worker. Dr Carlos Alberto Studart Gomes Hospital de Messejana, Fortaleza, Brazil.

\section{Isabela Melo Mattos}

Medical Student. Universidade Estadual do Ceará - UECE, Ceará State University - School of Medicine, Fortaleza, Brazil.

\section{Cyntia Maria Sampaio Viana}

Coordinator of the Pulmonary Rehabilitation Program at the Dr Carlos Alberto Studart Gomes Hospital de Messejana, Fortaleza, Brazil.

\section{Eanes Delgado Barros Pereira}

Associate Professor. Universidade Federal do Ceará - UFC, Federal University of Ceará - School of Medicine, Fortaleza, Brazil. 